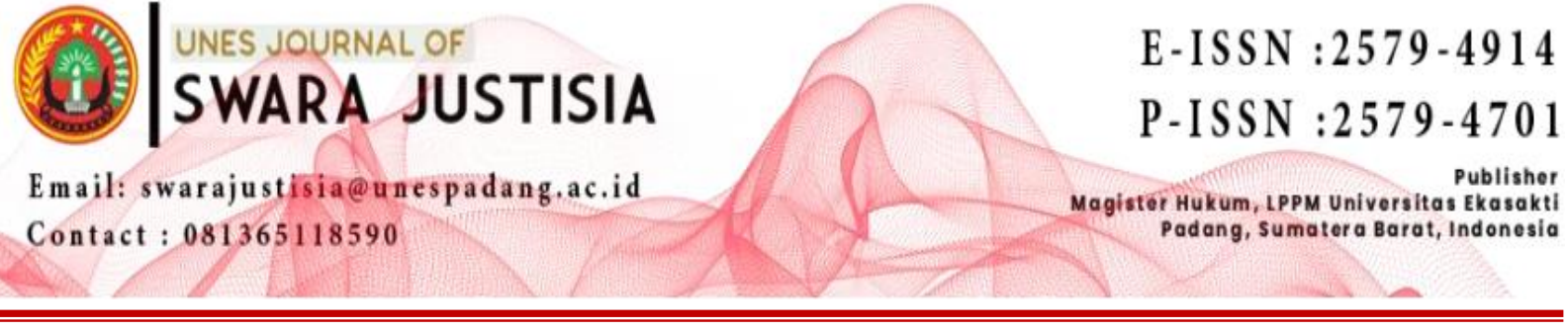

\title{
PENETAPAN TERSANGKA DALAM PENYIDIKAN TINDAK PIDANA PENGGUNAAN BAHAN TAMBAHAN YANG MELAMPAUI AMBANG BATAS PADA PRODUK PANGAN OLAHAN (Analisis Laporan Polisi Nomor : LP/173/A/VI/2017/Spkt Sbr)
}

\author{
Dito Landerson \\ Program Magister Ilmu Hukum,Universitas Ekasakti, Padang, Indonesia \\ Email: ditolanderson12@gmail.com
}

\begin{abstract}
The use of food additives is regulated in Law Number 18 of 2012 concerning Food. Additives are used to improve the quality and durability of food, but additives contain substances that are harmful to health, so there are restrictions on their use. Although there is a threshold for its use, it is still found that there are foodstuffs that violate these provisions, as is the case in the police report number LP/173/A/VI/2017/SPKT SBR. For this reason, an investigation is needed, so that the suspect can be charged with legal provisions.
\end{abstract}

Keywords: Investigation, Processing Products

\begin{abstract}
ABSTRAK
Penggunaan bahan tambahan pangan diatur dalam Undang-undang Nomor 18 Tahun 2012 tentang Pangan. Bahan tambahan digunakan untuk meningkatkan mutu dan daya tahan makanan, namun bahan tambahan mengandung zat berbahaya bagi kesehatan sehingga terdapat pembatasan pada penggunaannya. Meskipun terdapat ambang batas penggunaannya masih ditemukan adanya bahan pangan yang melanggar ketentuan tersebut, sebagaimana perkara dalam laporan polisi nomor LP/173/A/VI/2017/SPKT SBR. Untuk itu diperlukan penyidikan, sehingga dapat menjerat tersangka dengan ketentuan hukum.
\end{abstract}

Kata Kunci : Penyidikan, Produk Pengolahan

\section{PENDAHULUAN}

Kesehatan merupakan salah satu syarat dalam mencapai kesejahteraan hidup yang telah dijamin dalam Konstitusi Negara Republik Indonesia. Hal ini tertuang dalam Pasal $28 \mathrm{H}$ ayat (1) Undang-Undang Dasar Negara Republik Indonesia Tahun 1945, yang menyebutkan bahwa setiap orang berhak hidup sejahtera lahir dan batin, bertempat tinggal, dan mendapatkan lingkungan hidup yang baik dan sehat serta berhak memperoleh pelayanan kesehatan. Kesehatan menurut Pasal 1 angka 1 Undang-undang Nomor 36 Tahun 2009 tentang Kesehatan adalah keadaan sehat, baik secara fisik, mental, spritual maupun sosial yang memungkinkan setiap orang untuk hidup produktif secara sosial dan ekonomis.

Salah satu penunjang agar kesehatan dapat terwujud ialah dari asupan gizi dalam makanan yang dikomsumsi sehari-hari. Dalam hal ini Negara berkewajiban mewujudkan ketersediaan, keterjangkauan dan pemenuhan konsumsi Pangan yang cukup, aman, bermutu 
dan bergizi seimbang, baik pada tingkat nasional maupun daerah hingga perseorangan secara merata di seluruh wilayah Negara Indonesia di sepanjang waktu dengan memanfaatkan sumber daya, kelembagaan dan budaya lokal.

Bahan pangan atau makanan yang dikonsumsi sehari-hari, harus memenuhi standart kesehatan, adapun definisi makanan yang sehat adalah makanan yang tidak mengandung bahan yang dapat merugikan mahluk hidup yang mengkonsumsinya. Namun masyarakat cenderung mengabaikan kwalitas makanan dengan mengutamakan rasa, sehingga sering menggunakan tambahan bumbu atau bahan lain seperti penyedap rasa, kecap, saus dan yang lainnya. Tanpa memperdulikan efek yang akan diterima oleh tubuh. Bahaya penggunaan bahanbahan tambahan dalam makanan relatif lama tergantung dengan keadaan dan ketahanan tubuh.

Penambahan bahan kedalam makanan sudah dikenal sejak ratusan tahun yang lalu oleh manusia. Tujuan penambahan bahan atau zat-zat tertentu ke dalam makanan secara umum adalah untuk meningkatkan nilai gizi makanan, memperbaiki nilai estetika dan sensori makanan dan memperpanjang umur simpan (shelf life) makanan. Namun, didalam penggunaannya harus diberikan batasan dengan istilah ambang penggunaan.

Terdapat pengertian bahan tambahan yang digunakan dalam bahan pangan disebutkan dalam Pasal 1 angka 2 Peraturan Kepala Badan Pengawas Obat Dan Makanan Republik Indonesia Nomor 36 Tahun 2013 tentang Batas Maksimum Penggunaan Bahan Tambahan Pangan Pengawet, yang menyebutkan bahwa:

Bahan Tambahan Pangan, selanjutnya disingkat BTP, adalah bahan yang ditambahkan ke dalam pangan untuk mempengaruhi sifat atau bentuk pangan.

Bahan tambahan makanan adalah bahan yang ditambahkan dengan sengaja kedalam makanan dalam jumlah kecil, dengan tujuan untuk memperbaiki penampakan, cita rasa, tekstur, flavor dan memperpanjang daya simpan. Pengawetan makanan pada dasarnya dapat dilakukan secara alami dengan penggunaan garam atau dengan mengeringkan makanan. Namun, tidak semua makanan dapat diawetkan menggunakan cara ini. Oleh sebab itu, banyak penggunaan bahan kimia untuk proses pengawetan makanan. kebanyakan pengawet makanan berbahan kimia yang digunakan aman untuk dikonsumsi setiap hari, namun, terdapat beberapa jenis pengawet makanan berbahaya yang patut diwaspadai. Konsumsi bahan pengawet berbahaya dalam kurun waktu yang lama, dapat menyebabkan masalah kesehatan serius.

Produk pangan olahan yang sering dijumpai sebagai bahan penambah cita rasa makanan ialah kecap, saus sambal. Kandungan yang ada dalam kecap atau saos yang ada dipasaran salah satunya ialah bahan pengawet, dimana digunakan untuk dapat menjaga agar bentuk dan rasa yang terdapat didalamnya dapat bertahan lebih lama. Sebagaimana yang disebutkan dalam Pasal 1 angka 4 Peraturan Kepala Badan Pengawas Obat Dan Makanan Republik Indonesia Nomor 36 Tahun 2013 tentang Batas Maksimum Penggunaan Bahan Tambahan Pangan Pengawet, menyebutkan bahwa:

Pengawet (preservative) adalah bahan tambahan pangan untuk mencegah atau menghambat fermentasi, pengasaman, penguraian, dan perusakan lainnya terhadap pangan yang disebabkan oleh mikroorganisme.

Salah satu bahan pengawet yang terdapat pada kecap ialah asam benzoate yang disebut juga sebagai senyawa antimikroba karena tujuan penggunaan zat pengawet ini dalam 
produk kecap adalah untuk mencegah pertumbuhan khamir dan bakteri terutama untuk makanan yang telah dibuka dari kemasannya. Pengawet makanan sodium benzoate seringkali digunakan dalam proses produksi berbagai macam produk makanan dan minuman kemasan. Penggunaan bahan pengawet ini biasanya tercantum pada label kemasan sebagai daftar bahan dasar produk tersebut.

\section{PEMBAHASAN}

A. Penetapan Seseorang Menjadi Tersangka Oleh Penyidik Direskrimsus Polda Sumbar Dalam Penyidikan Tindak Pidana Penggunaan Bahan Tambahan Pada Laporan Polisi Nomor LP/173/A/VI/ 2017/Spkt Sbr

Berdasarkan ketentuan Pasal 1 angka 14 Undang-undang Nomor 8 Tahun 1981 tentang Hukum Acara Pidana menyebutkan bahwa tersangka adalah seorang yang karena perbuatannya atau keadaannya, berdasarkan bukti permulaan patut diduga sebagai pelaku tindak pidana. Pada tahapan ini seseorang ditetapkan sebagai tersangka hanya berdasarkan bukti permulaan yang didapat dari hasil penyelidikan yang dilakukan oleh kepolisian.

Keputusan penyidik untuk menetapkan seseorang sebagai tersangka merupakan tindak lanjut dari sebuah proses hukum penyelidikan yang dilakukan oleh kepolisian. Pasal 25 Peraturan Kepala Kepolisian Negara Republik Indonesia Nomor 6 Tahun 2019 tentang Penyidikan Tindak Pidana menyebutkan bahwa:

1) Penetapan tersangka berdasarkan paling sedikit 2 (dua) alat bukti yang didukung barang bukti.

2) Penetapan tersangka sebagaimana dimaksud pada ayat (1), dilaksanakan melalui mekanisme gelar perkara, kecuali tertangkap tangan.

Berdasarkan aturan di atas, dapat dikatakan bahwa untuk menetapkan seseorang sebagai tersangka tindak pidana harus ada minimal 2 buah alat bukti permulaan yang nantinya dapat dijadikan sebagai dasar hukum oleh penyidik dalam menetapkan seseorang itu adalah tersangka.

Berdasarkan hasil penelitian terhadap penyidikan tindak pidana penggunaan bahan tambahan pada produk pangan olahan sebagaimana laporan polisi nomor LP/173/A/VI/2017/Spkt Sbr, yang ditangani Subdit I Indagsi (Industri, Perdagangan dan Asuransi) Direktorat Reserse Kriminal Khusus (Ditreskrimsus) Kepolisian Daerah Sumatera Barat. Menurut AKBP Yunizar Yudhistira, S.H, M.H, terdapat tindakantindakan yang dilakukan oleh penyidik berdasarkan ketentuan dalam KUHAP dan Peraturan Kepala Kepolisian Negara Republik Indonesia Nomor 6 Tahun 2019 tentang Penyidikan Tindak Pidana, maka penetepan tersangka dalam perkara tersebut penyidik berpijak pada alat bukti yang diperoleh penyidik berupa keterangan saksi, keterangan ahli, surat, petunjuk dan keterangan terdakwa.

Adapun tindak pidana ini terungkap setelah anggota Subdit I indagsi Ditreskrimsus Polda Sumatera Barat melakukan penyelidikan berdasarkan dengan Surat Perintah Penyelidikan Nomor SP.Lidik/67/V/2017/Ditreskrimsus, tanggal 10 Mei 2017. Sebagaimana yang diketahui pada bab sebelumnya, dalam melakukan penyelidikan tersebut salah satu dari anggota Subdit I Indagsi Ditreskrimsus membeli sampel kecap yang diperjualbelikan di pasaran. Dari kemasan tersebut polisi mengetahui alamat tempat pembuatan kecap dan sambel produksi perusahaan cahaya Baru. 
Selanjutnya, polisi mendatangi lokasi perusahaan Cahaya Baru, ditemukan karyawan perusahaan Cahaya Baru sedang memproduksi kecap dan sambel dan beberapa orang karyawan sedang melakukan pengolahan dan pembungkusan terhadap hasil produksi berupa kecap dan sambel dan ditemukan juga bahan baku berupa tepung, gula aren, rempah-rempah, garam, pewarna, perasa, sari kedelai serta bahan tambahan pangan berupa Natrium Benzoat dan Cyclamate serta tawas yang digunakan sebagai bahan tambahan pangan dalam pembuatan kecap dan sambel tersebut.

Hasil produksi berupa kecap dan sambal dilakukan pengambilan sampel oleh penyidik untuk pengujian secara laboratorium. Berdasarkan hasil uji laboratorium yang telah dilakukan oleh BPOM Kota Padang, ditemukan Sodium benzoat dan Cyclamate dalam kandungan kecap tersebut diatas yang melebihi ambang batas untuk pangan. Penyidik melakukan upaya paksa berupa penyitaan terhadap barang bukti yang berhubungan dengan perkara berdasarkan SP.Sita/08/VII/2017/ Ditreskrimsus tanggal 3 Juli 2017, telah dilakukan penyitaan terhadap barang bukti.

Berdasarkan Surat Perintah Penyitaan tersebut diatas telah dimintakan Penetapan Penyitaan kepada Ketua Pengadilan Negeri Padang Nomor: B/08.c /VII/2017/Ditreskrimsus, tanggal 19 Juli 2017, telah diterbitkan Surat Penetapan Penyitaan Penyitaan dari Ketua Pengadilan Negeri Padang Nomor : 531/P.VII/Pen.Pid/2017/PN.PDG, tanggal 27 Juli 2017.

Berdasarkan penyitaan barang bukti kemudian Penyidik Ditreskrimsus Polda Sumatera Barat menerbitkan surat perintah penyidikan nomor: Sp. Sidik/ 23/VII/2017/Ditreskrimsus, tanggal 3 Juli 2017 yang kemudian diterbitkannya surat pemberitahuan dimulainya penyidikan nomor: SPDP/12/VII/2017/ Ditreskrimsus, tanggal 5 Juli 2017 ke Kejaksaan Negeri Padang.

Setelah dilakukan penyitaan oleh penyidik, maka dilakukan pemanggilan dan pemeriksaan terhadap saksi-saksi yaitu:

1. Saksi Tio Setiawan Pgl Tio anggota Kepolisian Dinas di Subdit I Ditreskrimsus Polda Sumbar

2. Saksi Yudi Prasetio, S, Sos Pgl Yudi anggota Kepolisian Dinas di Subdit I Ditreskrimsus Polda Sumbar,

3. Saksi Heendri Pahmi Pgl Pahmi Alias Ajo, Saksi Ernawati Pgl Erna,

4. Saksi Yusra,Amd Pgl Era,

5. Saksi Djoni Pgl Djoni,

6. Saksi Silvia Yusnita, SE Pgl Via,

7. Romi Harianto Pgl Romi,

8. Saksi Khairul Abdullah, S.Kom Pgl Rul,

9. Saksi Afdinal Agus Pgl Nal, Saksi Pgl Bob,

10. Saksi dari Dinas Kesehatan Provinsi Sumatera Barat atas nama Dra.Yudihartati, M.Farm, Apt Pgl Nanik,

11. Saksi dari Dinas Perindusterian Perdagangan Provinsi Sumatera Barat atas nama Syahrial, MM,

12. Saksi dari Badan Pengawas Obat dan Makanan Padang atas nama Yonfirman, Ssi, Apt $\mathrm{Pgl}$ Yon,

13. Saksi dari Dinas Kesehatan Kota Padang atas nama Indrawati.A, SH. M.Sc Pgl In 
14. Tersangka Iskandar Salim Alias Awa.

Dalam menemukan bukti permulaan yang cukup agar tindak pidana dapat diungkap, maka dilakukanlah gelar perkara. Gelar perkara adalah suatu upaya berupa pegelaran proses perkara yang dilakukan oleh penyidik dalam rangka menyelesaikan tindak pidana secara tuntas guna menetapkan si tersangka oleh penyidik.

\section{B. Kendala Yang Dihadapi Penyidik Direskrimsus Polda Sumbar Dalam Penetapan Seseorang Menjadi Tersangka Tindak Pidana Penggunaan Bahan Tambahan Pada Laporan Polisi Nomor LP/173/A/VI/ 2017/Spkt Sbr Dan Upaya Mengatasi Kendala Tersebut}

Terkait dengan kendala yang ditemui penyidik berdasarkan dari hasil penelitian, maka peneliti menemukan beberapa poin kendala dalam kegiatan penyidik dalam menetapkan tersangka yang meliputi, dalam menetapkan tersangka penyidik harus mengadakan pemeriksaan saksi yang cukup banyak dan harus menunggu hasil laboratorium berupa beberapa sample produk makanan yang diproduksi oleh perusahaan tersebut. Banyaknya saksi yang hanya menjalankan pekerjaan dalam pabrik kegiatan produksi kecap pada perusahaan Cahaya Baru tersebut.

Sehingga penyidik membutuhkan waktu yang lama untuk menentukan tersangkanya serta menentukan keterlibatan pihak lain dalam perkara tersebut. Saksi-saksi yang telah dilakukan pemeriksaan oleh pihak penyidik Ditreskrimsus Polda Sumatera Barat pada umumnya menerangkan bahwa tidak mengetahui terkait penggunaan campuran bahan-bahan pengawet seperti Sodium Benzoate dan Cyclamate dalam produksi kecap dan sambal tersebut. Adapun jumlah saksi yang merupakan kariawan pada Perusahaan Cahaya Baru yang dipimpin oleh Iskandar Salim adalah sebanyak 9 (sembilan) orang.

Dalam hal ini justru si peracik bumbu atau jumlah takaran dalam membuat kecap dan sambal dengan menggunakan bahan tambahan pangan tidak dimintai pertanggung jawaban dikarenakan si peracik merupakan karyawan yang bekerja di bawah perintah tersangka yaitu pemilik pabrik tersebut. Adapun yang menjadi karyawan Perusahaan Cahaya Baru yang meracik kecap adalah Hendri Fahmi Pgl Ajo dan peracik sambel adalah Ernawati Pgl Erna dan peracik Asam Cuka adalah Delinar Pgl Del. Tersangka menerangkan bahwa yang menunjuk saudari Ernawati Pgl Erna sebagai penanggung jawab dalam memproduksi kecap pada Perusahaan Cahaya Baru adalah tersangka sendiri dan Saudari Ernawati Pgl Erna bekerja adalah di bawah kendali tersangka.

Berdasarkan hasil pemeriksaan oleh pihak kepolisian, didapatkan informasi bahwa ketika Ernawati Pgl Erna ataupun Hendri berhalangan hadir pada pekerjaannya tidak ada orang lain yang dapat menggantikan posisi Ernawati Pgl Erna dan Hendri sebagai peracik sambal maupun kecap tersebut.

Dalam keterangannya, Erna menerangkan bahwa dia bekerja sebagai karyawan di perusahaan kecap dan sambal Cahaya Baru, tugas tanggung jawab Erna adalah sebagai peracik bahan-bahan untuk pembuatan sambel dan bekerja pada perusahaan Cahaya Baru tersebut semenjak tahun 1998.

Sehingga tidak tertutup kemungkinan adanya keterlibatan peracik bahanbahan yang akan digunakan dalam produksi kecap maupun sambal tersebut. Namun si peracik mengaku bahwa dia hanya menjalankan pekerjaannya sesuai dengan apa yang diperintahkan oleh tersangka, karena tersangka merupakan penanggung jawab atau 
pimpinan pada perusahaan Cahaya Baru tersebut. Kemudian terkait pemilik perusahaan meminta penangguhan penahanan dengan alasan kesehatan, sehingga proses pemberkasan perkara tersebut membutuhkan waktu lama hingga harus mengumpulkan bukti transaksi keuangan dan memeriksa agen distributor guna mengetahui sebaran produk pangan olahan yang mengandung benzoat secara melawan hukum.

Banyaknya peraturan yang terkait dengan perbuatan tersangka. Sehingga penyidik membutuhkan waktu yang lama dalam menentukan pasal yang tepat untuk menjerat perbuatan tersangka. Selanjutnya terkait dengan kewenangan yang juga dimiliki oleh beberapa pihak yaitu antara penyidik Polri dengan Penyidik Pegawai Negri Sipil (PPNS) sehingga penyidik Ditreskrimsus Polda Sumatera Barat terhambat dalam kewenangannya untuk melakukan penyidikan tindak pidana pangan yang juga merupakan kewenangan Penyidik Pegawai Negeri Sipil, sehingga penyidik Ditreskrimsus harus berkoordinasi terlebih dahulu dengan Penyidik Pegawai Negeri Sipil.

Terkait penyidikan tindak pidana penggunaan bahan tambahan yang melampaui ambang batas pada produk pangan olahan yang terjadi di Kota Padang, merupakan kewenangan dari Pejabat Pegawai Negeri Sipil tertentu di lingkungan Pemerintahan Daerah. Hal ini sesuai dengan Undang-undang Republik Indonesia Nomor 18 Tahun 2012 tentang Pangan, penyidikan dalam tindak pidana di bidang pangan dapat dilakukan oleh penyidik Polri dan penyidik PPNS, yang menyebutkan bahwa:

Pada Pasal 132 menerangkan bahwa:

1) Selain pejabat polisi negara Republik Indonesia, pejabat pegawai negeri sipil tertentu yang lingkup tugas dan tanggung jawabnya di bidang Pangan diberi wewenang khusus sebagai penyidik untuk melakukan penyidikan dalam tindak pidana di bidang Pangan sesuai dengan ketentuan peraturan perundang-undangan di bidang Hukum Acara Pidana.

2) Penyidik pegawai negeri sipil sebagaimana dimaksud pada ayat (1) berwenang: a. Melakukan pemeriksaan atas kebenaran laporan atau keterangan berkenaan dengan tindak pidana di bidang Pangan; b. Melakukan pemanggilan terhadap seseorang untuk didengar dan diperiksa sebagai tersangka atau sebagai saksi dalam tindak pidana di bidang Pangan; c. Melakukan penggeledahan dan penyitaan terhadap barang bukti tindak pidana di bidang Pangan; d. Meminta keterangan dan barang bukti dari orang atau badan hukum sehubungan dengan tindak pidana di bidang Pangan; e. Membuat dan menandatangani berita acara; f. Menghentikan penyidikan apabila tidak terdapat cukup bukti tentang adanya tindak pidana di bidang Pangan; dan g. Meminta bantuan ahli dalam rangka pelaksanaan tugas penyidikan tindak pidana di bidang Pangan.

3) Penyidik pegawai negeri sipil sebagaimana dimaksud pada ayat (1) memberitahukan dimulainya penyidikan kepada pejabat penyidik kepolisian negara Republik Indonesia.

4) Apabila pelaksanaan kewenangan sebagaimana dimaksud pada ayat (2) memerlukan tindakan penangkapan dan penahanan, penyidik pegawai negeri sipil melakukan koordinasi dengan pejabat penyidik kepolisian negara Republik Indonesia sesuai dengan ketentuan peraturan perundang-undangan.

5) Penyidik pegawai negeri sipil sebagaimana dimaksud pada ayat (1) menyampaikan hasil penyidikan kepada penuntut umum melalui pejabat penyidik kepolisian negara Republik Indonesia. 
6) Pengangkatan pejabat penyidik pegawai negeri sipil dan tata cara serta proses penyidikan dilaksanakan sesuai dengan ketentuan peraturan perundang-undangan.

Namun, karena tindak pidana penggunaan bahan tambahan yang melampaui ambang batas pada produk pangan olahan sebagaimana dalam laporan polisi nomor LP/173/A/VI/2017/Spkt Sbr, terkait dari penggunaan bahan tambahan yang melampaui ambang batas pada produk pangan olahan tersebut ternyata tidak hanya menyangkut aspek pengawasan dan perizinannya, tetapi juga akibatnya atau efek sampingnya, seperti terjadinya gangguan kesehatan serta kematian akibat mengkosumsi makanan yang menggunakan bahan pengawet atau bahan tambahan pangan yang melampaui ambang batas maksimal yang telah ditetapkan undang-undang.

\section{KESIMPULAN}

1. Penetapan seseorang menjadi tersangka oleh Penyidik Direskrimsus Polda Sumbar dalam penyidikan tindak pidana penggunaan bahan tambahan pada laporan polisi nomor LP/173/A/VI/2017/Spkt Sbr yaitu diawali pemeriksaan terhadap pekerja perusahaan cahaya baru yang menerangkan bahwa penggunaan bahan tambahan sudah ditentukan dalam resep pembuatan kecap dan saus oleh pemilik perusahaan. Penggunaan benzoat pada produk tersebut ditujukan untuk memperpanjang masa kadaluarsa sehingga dapat menguntungkan perusahaan. Sehingga terpenuhinya unsur setiap orang yang menggunakan bahan tambahan yang melampaui batas dalam Pasal 75 ayat (1) huruf a Undang-undang Nomor 18 Tahun 2012 tentang Pangan berdasarkan keterangan saksi, keterangan ahli dan keterangan tersangka yang mengakui perbuatannya didukung dengan barang bukti, maka penyidik menetapkan pemilik perusahaan Iskandar Salim Alias Awa sebagai tersangka.

2. Kendala yang dihadapi Penyidik Direskrimsus Polda Sumbar dalam penetapan seseorang menjadi tersangka tindak pidana penggunaan bahan tambahan, terdiri dari kendala yuridis dan non yuridis yaitu pada pada kendala yuridis, dalam menetapkan tersangka harus menunggu hasil laboratorium dari BPOM, guna mencukupkan alat bukti dalam menetapkan tersangka, penyidik harus meminta keterangan ahli dari Dinas Kesehatan dan Dinas perdagangan terlebih dahulu, sehingga memakan waktu yang cukup lama. Selanjutnya kendala non yuridis yaitu penyidik tidak memiliki alat uji tersendiri. Adapun upaya penanggulangan kendala tersebut diadakan tindakan konfrontir kepada para saksi pekerja dan pemilik serta dikaitkan dengan keterangan ahli yang menerangkan bahwa sebagai pelaku usaha memiliki kewajiban beritikad baik dalam melakukan kegiatan usahanya.

\section{DAFTAR PUSTAKA}

Adami Chazawi, Pengantar Hukum Pidana Bag 1, Grafindo, Jakarta, 2002.

Cahyo Suparinto, Bahan Tambahan Pangan, Penerbit Kanesius, Yogyakarta, 2006

Damayanti, Komunikasi terapeutik dalam praktek keperawatan, Refika Aditama, Bandung, 2008.

HR. Ridwan, Hukum Administrasi Negara, PT. Raja Grafindo Persada, Jakarta, 2001 
Harmita, Amankah Pengawet Makanan Bagi Manusia. Majalah Ilmu Kefarmasian, FMIPAUI, Depok. Hartono, Penyidikan dan Penegakan Hukum Pidana Melalui Pendekatan hukum Progresif, Sinar Grafika, Jakarta, 2010.

Hamidi, Metode Penelitian Kualitatif. Aplikasi Praktis Pembuatan Proposal dan Laporan Penelitian, UMM, Malang, 2004. 